\title{
Management, evaluation
}

and school success: examples from Ceará's path

\section{SOFIA LERCHE VIEIRA}

"To look into the eyes of the tragedy is to begin to overcome it." (Oduvaldo Vianna Filho)

$\mathrm{E}$ DUCATION is a complex undertaking that represents a permanent challenge for humanity. In a knowledge society, the imperative of more and better education for all stands as an unpostponeable priority. For the most diverse reasons, throughout history, Brazil has confronted great difficulties in offering education in quantity and quality compatible with developmental needs and the population's rights as citizens. A comparison with educational indicators of other countries makes it clear that we are not close to resolving many of the questions that should have been already answered (cf. Vieira \& Vidal, 2007a). Thus we began the XXI century with an agenda of accumulated problems from the past and the present, with still more that we are beginning to confront. Even more seriously, we are not developing management for the school success of our children and young people.

In spite of the incalculable amount of resources invested in policies for expansion and improvement of the Basic Education level, a serious lack of assistance remains for this school level, in particular for Infant Education and the "High School," equivalent in age range to U.S. Senior High School, hereafter, High School (ibid.). ${ }^{1}$

The decision was therefore made to render "Médio" as its nearest equivalent in age range and position within the system, High School. With the introduction of "Cycles" as a replacement for "Grades" in some Brazilian systems further complicating terminology for translation the other nomenclature, Infancy and Fundamental, has been retained).

A good part of the infra-structure of the school network is precarious. The system for assistance is badly distributed, representing a heavy governmental burden in the cost of school transportation. We still have schools with only one classroom, lacking basic services like water and even bathrooms. Rare are the school libraries that manage not to look like book storage. If many schools have been bypassed by the new technologies, in others there is disuse or even computers still in their boxes for lack of resources for maintenance and/or installation. Books and other pedagogical materials exist but not always in 
sufficient number or adequate in quality. While in some subject areas there is an surplus of prepared teachers, in others there is a lack. Salaries are low and motivation rarely higher. An inventory of difficulties could go on, but the intent is not to look further into them here but rather to refer to them only for explaining the educational significance of looking "into the eyes of the tragedy."

If the tragedy is visible in the country as a whole, what can we say of the most impoverished regions? Certainly for them the problem is of greater scope (cf. Vieira \& Vidal, 2007b). This is the case with Ceará's difficulties, shared with many of the Brazil's Northeast states where the demand for education is high and resources reduced. Is there a distinct educational agenda for these populations? More than to diagnose the problems, the idea here is to point out alternatives that have been developed to confront the challenges of educational management in a context of scarcity of resources. To that end we refer to aspects of the experience of this state in the federation in the last decade, when measures were introduced with the aim of providing quality education for everyone

In order to position the reader, the text presents brief considerations concerning policies implemented between 1995 and 2002, with emphasis on some of the implications for the educational system of Ceará, as well as strategies that between 2003 and 2006 were adopted with an eye toward furthering its quality. Finally, we will focus on the question of continuity/discontinuity of policies keeping in mind their importance for the present discussion.

\section{“All for Quality Education for All” (1995-2002)}

In 1995, Tasso Jereissati began his second term as governor of Ceará, followed by reelection to a third term. As in the national plan, under the office of President Fernando Henrique Cardoso, so within the scope of the state there was continuity in the educational management. During the period to be examined between 1995 and 2002, as with other states in the federation, Ceará took large steps toward making the Fundamental School universal while expanding the High School. The government's project was summed up in the proposal "All for Quality Education for all," strongly emphasizing society's participation and its mobilization for education. ${ }^{2}$ Some peculiarities were decisive in Ceará's ongoing educational process during these eight years, however, two of which merit attention: the technical selection process and election of its directors, and an accelerated municipalization of the Fundamental School.

The process of selection and election of directors by the school community was introduced in the state system in 1995, having essentially continued similarly since then (cf. Vieira, 2006, p.27-42). Such innovation brought many gains from the point of view of a change in the power structure, representing a positive alternative to the previous criteria of political recommendations for directorial positions in the schools. By electing its directors, a more participative, felicitous and generally better managed school came to Ceará.

It is appropriate to observe, however, that there were not few difficulties encountered in developing a managerial process compatible with a decentralized 
school system. Thus, more frequently than desirable, school autonomy was taken to extremes through abandonment of the principles and norms that were common to the entirety of the system. A clear example of such a situation was the indiscriminate offering of disciplines that had been indiscreetly created by a management not always in possession of the most elementary notions concerning curricula. Because of the lack of an oversight system for tracking and controlling costs, it was difficult to provide a common level of maintaining as well as improving the physical network. Each school thus became a small island where the power of the directors flourished, not always propitiously for school success.

Although school performance improvement had been the intent of the implemented policies, with Ceará expected to rank among states with higher performance levels in the Basic Level Evaluation System (SAEB), management democratization did not translate into improvements in the student learning results indicators. At least not in the manner in which these are measured by the state or federal evaluation systems. ${ }^{3}$ On the contrary, in the years following the implementation of the process, the learning scores became worse. It is true that such a situation was not specific to Ceará, but in fact an expression of a national tendency toward declining income that, to be sure, was accompanied by an extraordinary increase at the time of available jobs.

During the period corresponding to the two last terms of Tasso Jereissati, another process that was deliberately pursued was the municipalization of the Fundamental School. Ceará, which already had a strong municipal presence in its basic education offering, oriented itself toward courting politics in the sense that, beginning in 1995, within a short period of time it became the state with the highest enrollment rate in the Federation's circuit of municipal systems. From this perspective, it had by itself anticipated implementation of the National Development Fund for the Fundamental School and Teaching Valorization (FuNDEF), which came to be an instrument for facilitating the objectives being pursued.

In a context in which resources tied to education came to be distributed in conformity with enrollments by the school systems, the municipalities had an unprecedented interest in an offer at this level. A good part of the revenues linked to the state government came to be transferred to FuNDEF, passing on assumption of responsibility to the government for nearly two thirds of the costs of the Fundamental School in the municipalities. Meanwhile, the federal government's portion was negligible, having contributed very little to FuNDEF revenue in Ceará. Such a situation had grave repercussions in relation to investments and maintenance of schools in the state, since the tax revenue only barely covered the financing of the Fundamental School and its salaries.

\section{“Better School, Better Life" (2003-2006)}

As a quite poor state, Cearás unprecedented expansion beginning in the middle of the 1990s represented a heavy burden on the public sector. Such a situation can be seen to have been aggravated by various factors, including the tax burden in relation to maintaining a school system composed of three universities, 
with many branches distributed throughout the state. In this context defining priorities became an urgent and indispensable task. Under these circumstances planning and choosing the principle focus of the work to be developed was the first step given to the 2003-2006 government.

The perspective sought after was from the standpoint of responsible planning which would walk away from the many unfulfilled promises from the plentiful plans for education. ${ }^{4}$ Thus four guiding principles and ten priority programs were defined which came to be the guiding thread of all the Basic Education management work accomplished in the four years of Lúcio Alcântara's government. ${ }^{5}$ Educational management is not a simple process. The requirements are many, resources scarce and opposition is frequently intransigent. Thus developing a simple and viable education plan became in itself an adequate and important strategy in the process of definition of the policies adopted during this period. The plan was reproduced on a large scale, disseminated in various forums, distributed to all the schools of the state network. It was integrated into the bibliographical list of the public selections and civil service exams given at the time, and came to be fully known and discussed throughout the state.

In this article we are going to reflect on elements that permeated the whole of the programs/challenges with direct impact on learning. The guiding thread of the reflection is the idea of management for a community of learners, understanding that this can be broken down into a series of factors that can offer proper conditions for making a school successful. Some of these factors are going to be examined here in greater detail, in particular the question of school performance as an indicator of success, the role of the evaluation systems in this process, the search of a management for results and the possible impact of a culture of evaluation on the school system of Ceará. These ideas will be discussed in greater depth in the following topics.

\section{Management for a successful school -the essence of the educational task}

Facing the not rare innumerable difficulties and necessities that arose in regard to the promotion of school education, the formulators and executors of educational policy set aside the essence of the educational task, concentrating on half-way measures. It is thus vital that management always be mindful that "the school is the institution that humanity created in order to put systematized knowledge into practice in society" (Penin \& Vieira, 2002) and that everything must to be done to ensure that its social function can become successful. The persistence of school failure among so many children and young people in diverse parts of the world makes it imperative to reaffirm the appropriateness of the school

as a space for the meeting of students and teachers, configured as a community of learners. Its reason for being is intrinsically tied to the underlying task of good teaching and learning. A successful school management, therefore, is one that is oriented toward learning on the part of all the students.

(Vieira, 2006) 
Since the school itself is an appropriate place for spreading knowledge, all efforts should converge on the learning process of those for whom it was created - whether children, from very young ages, young people or adults. Despite the obviousness of such an affirmation, it is necessary to insist on it. There are so many problems in practice that the management runs the risk of diverting itself from this so apparently obvious goal. Of losing itself by getting tied up in new daily entanglements. And as we well know, this can not and should not occur. The success of school management is finally solidified only by the success of all students. That is why it is necessary to maintain as pole-star "management for a community of learners." From this perspective the central concern of the Basic Education Plan "Better School, Better Life" was oriented toward "guaranteeing the quality of the school with focus on student learning" (Ceará, 2004a, p.624). Support for this was sought from various facets of management, one of them being the use of resources deriving from existing evaluation systems, in the sense of pursuing them as a goal of the school's activity.

\section{Systems of evaluation-school performance as a gauge of success}

It is well known that universalizing the Fundamental School represented an important victory in expanding social segments that had previously lacked access to school.

Such circumstances brought new challenges to the policy and systems management, responses to which were not always compatible with the new demands. School in turn had difficulties adjusting to a clientele that originated from families for whom literacy was not always incorporated into their daily lives. Although elevated investments had been made to develop education for all, there is still much to be done in relation to effective improvement of the educational system. Management is a significant part of this undertaking.

In the context of expanding educational opportunities, controversy became more intense in Brazil with critics' fights over school quality. As in the country as a whole, so it is for states and municipalities. The principle has held true for Ceará as well. The maxim, certainly, is not original: on the contrary, it has been the case since the beginning of Brazilian public education. ${ }^{6}$ The enlargement of contingent populations, however, increased both the volume and tone of complaints about its conditions with respect to functioning and management.

It is well to remember that we have good and bad schools just as anywhere else in the world, whether in the public or private sector. At the same time, studies and field research in cognitive development have provided evidence that with appropriate conditions an overwhelming majority of students have the potential to achieve school success. Thus it is necessary to continue searching for alternatives that can make this possible. Evaluation of the school systems has been one of the strategies followed in this direction.

In comparison with other countries, Brazilian students' performance has been quite negative, as shown in data from the Program International 
of Student Evaluation (PISA) (OCDE, 2005). Conceived by the Organization for the Cooperation and Economic Development (OCDE), in response to the need for international measurement and comparison of students, the PISA study was conducted for the first time in 2000, and applied again in 2003 and 2006. Brazil presented one of the weakest performances among the original or invited of the $4 \mathrm{l}$ countries taking part. Such an outcome puts into question the success of the educational policies developed in recent decades. After all is said and done, are our children learning or are they not? With this query in mind, it is appropriate to continue reflecting.

\section{Permanent Evaluation System for Basic Education-Cearás route}

Interest in evaluating our country's educational systems is relatively recent. Only at the beginning of the last decade did we institute a national evaluation policy, expressed through the creation of a Basic Education Evaluation System $(\mathrm{SAEB})^{7}$ in the form of the National High School Exam (ENEM) and the National Course Exam (ENC) known as "Provão." Such instruments have offered components for understanding the dimensions of Brazilian students' performance problems, showing that there is much to be done so that Brazil may be on the same level with the countries that have found a way to advance its students' school success.

Together with the educational policies developed by the nation during the same period, experiments in the systemic evaluation of school performance in various units of the federation have also arisen. Ceará in 1992 was one of the first states in the federation to create a statewide system beginning with the pilot experiment Evaluation of School Results of Students from $4^{\text {th }}$ and $8^{\text {th }}$ grades (evaluation of fourths and eighths) in a sampling of 156 schools of the state system and 14,600 students from $4^{\text {th }}$ and $8^{\text {th }}$ grades of the city of Fortaleza's Fundamental School.

The Permanent System of Basic Education Evaluation of Ceará (SPAECE), under various names and modifications throughout its implementation, was created to provide assistance in formulating educational policies oriented toward improvement of learning based on the indications of students' school performance. From an initial trial limited to only one municipal district, SPAECE was gradually extended, at first to the fourteen municipal districts headquarters of the previous Departments of Regional Educational (DERE) that total today 21 Regional Centers of Educational Development (CREDE). In 2003 it was extended to all of Cearás cities, to 28,557 students in the Fundamental School's $8^{\text {th }}$ grade and the $3^{\text {rd }}$ grade of the High School.

In 2004 a major and more significant change occurred in SPAECE, when it went on to involve assessment in the entire municipal school system evaluating the largest contingent of schools and students since its inception. In this year 2,631 public (state and municipal) schools and 187,577 students were evaluated: 72,787 from the state and 114,790 from the municipal system. Participating as well by response to questionnaires were 2,600 directors and 9,550 teachers from 
the schools /grades being evaluated. The groupings were maintained from the $4^{\text {th }}$ and $8^{\text {th }}$ grades of the Fundamental and the High School's $3^{\text {rd }}$ grade in the Portuguese language and mathematics fields.

Carrying out such a comprehensive evaluation represented a very important victory for the state. Never at any previous moment of educational policy had such a faithful picture of student performance been obtained, in both content areas and grades tested.

It is true that the results of SPAECE in 2003 and 2004 revealed results below expectations and failed to correspond to the government's investment in Basic Education. But there is a very important aspect to the results of SPAECE/2004 to be highlighted with reference to the use of its pedagogical potential.

With the system then implemented, the Ceará public system has gone on to present different types of reports (General Report, Regional Reports, Pedagogical Reports and School Bulletins), that have been published and widely distributed throughout the state. Although this might not seem like much, even if the results leave us uneasy, it was an unprecedented advance in the building of a management for school success.

In effect we are considering an innovation here that has strong potential for turning school failure around. For the first time we are working with instruments that help the school to comprehend its own performance, identifying weaknesses and potentialities, which represents an important tool for improvement. This work was done in all of the regions and municipalities of the state without distinction between municipal and state schools. Improvement of the public school requires this kind of understanding as well as a perception of a unified school system.

The job of putting result indicators into practice involves a pedagogy of diffusion. Nothing of what had been done was punitive in character, but on the contrary attempted to assess the dimensions of the teaching-learning problems, as well as the ranges of excellence for the public system as a whole. Some questions are inevitable within this context. Why are some schools more successful at promoting school success than others? What does this have do with management? The existence and adaptation of the usable indicators offer the school community components for the construction of an evaluation culture involving multiple dimensions. In the next topic we will dig into this idea somewhat further.

\section{Management for results - an inflection in the culture of public policies}

In the measured quest for improvement of the results of public administration commitments were written into the government's plan "A better Ceará" (2003-2006), for education to mesh with the axis of "Ceará, A Better Life," as elaborated in the "Better School, Better Life" plan for basic education previously referred to. One of the ten challenges that it contained directly expresses the theme presently being treated- "the perfection of the institutional evaluation and analysis of the educational results" (Ceará, 2004a, p.70-1). 
To provide continuity to the commitments assumed by the government, two important instruments were created for monitoring policy: Management for Results (GPR) coordinated by the Secretary of Planning and Coordination (SePlan), mediated by the Institute of Research and Economic Strategy of Ceará (IPECE) (Ceará, 2004b), and the System of Social Inclusion (SIS), which in turn expressed itself in conjunction with Aims of Social Inclusion (MIS) for all of the areas of the government (Ceará, s. d.). In education, as in other areas of public management, this step represents a clear divider of waters.

Management for results is a recent concern in the field of educational policy. For a considerable time, it was oriented toward being a process culture, leaving the challenge of building a results culture to the present time. It is clear that promoting participation is an indispensable component of the pedagogical process, for which Ceará has unswervingly remained on the road to democratic management, having been one of the few Brazilian states, as already seen, with an accumulated experience of its leaders having been chosen by the community school for more than ten years. Democracy is the system of government which seeks to universalize rights for all. School is an excellent place to promote quality education as an "inalienable human right" (Braslavsky, 2005). It is therefore school success that justifies democratic management and not the contrary. It is not enough, then, to be inclusive and happy. It is necessary to seek quality and in one manner or another this is expressed in the results obtained by the school.

It is true that we still do not have indicators capable of translating school quality in perfect or even satisfactory terms. As a matter of fact the complexity of education may not even allow a perfect model to be constructed. It is possible, however, to begin with the results that are available, work with them and go little by little toward building a culture of evaluation. Will it be an easy task? Certainly not. If it were easy, others would certainly have found the formula for success.

If the challenge of governing resides in "making decisions about complex questions" (Cordeiro, 2004), it is time to face the unique responsibility of building management for a community of learners. We will go into more detail about some aspects of this challenge.

\section{Policy and educational management- the use of indicators in the definition of priorities}

As we have seen previously, the building of evaluation systems is a recent phenomenon in Brazilian educational policy. The same can't be said, however, for other modes of data gathering, an example being the School Census, the origins of which began with the Emperor and are updated annually. In spite of having this enviable instrument for monitoring some relative aspects of services, infra-structure and the human resources that are involved, the use of available data has not been sufficiently explored by the educational system any more than by the schools.

Basic information such as schooling rates in relation to "Infantil Education" and Fundamental and High Schools tend to be forgotten in expanding offerings that many times follow the pressures of demand and the 
system's response capacity. The same can be said about valuable information like the size and quantity of the school buildings and installations. It is known that we have an excess of units to offer. The difficulty of having basic standards of quality in a system with excessively small schools is generally understood. Educational policies, however, have not been explicitly oriented toward stimulating state and municipal systems to promote a centralized school structure.

These are only simple examples of the data not having been used for educational policies at various levels. We want to make clear with this that it is insufficient to only obtain information and results. Incorporation into planning, execution and follow up of the referred to policies is essential. This is related to the central and intermediate organs of the system, but also to the schools.

The data doesn't speak by itself. The task of understanding and making it speak is ours. We can't avoid it. Our need for transforming the available data into information and the information into knowledge is urgent.

Many countries have rolled up their sleeves and been successful at the task of installing a culture of evaluation. It is not a matter of digging into such experiences here, but of remembering that when disseminating the schools' results there were not few mistakes made. Because of this we should work carefully and with civility at the strategies for publicizing the results.

The first thing is to look at the data without fear. The epigraph of this article offers us a route: "to look into the eyes of the tragedy." Why not? We can't hide from ourselves what the data insist on showing us. So we begin by recognizing that the problem exists. In order not to sweep the dirt under the rug, as our grandparents would say ... It seems simple, but it is an undertaking of complex breadth and execution, to which the Secretary of Basic Education of Ceará dedicated a good part of its energy between 2003 and 2006. A strategy of diffusion requires many steps: transparent relations with the media, production of materials, translation of information in an accessible manner to the school community, etc. It is worth noting that an important part of this process resides in the documentation of procedures which assure a common standard of services. To this end and not by chance alone were numerous instruments elaborated which came to be included among the 104 publications produced by Edições SEDUC during that time.

As important as spreading the results is the creation of conditions for the schools to recognize themselves in the data, as previously mentioned in this text. The treatment of the information should reach a level of detail that is greater any generalizations. The affirmation that the school is doing poorly is empty if continued on this level. For this it is necessary to have results from the school and to make them available to the school management, which in turn needs to incorporate such knowledge by expressing it as a strategy for reversing the school failure.

\section{Management and school success - building a culture of evaluation}

The task of building a culture of evaluation requires courage, determination and discernment. Much was done in the realm of the central 
departments (SEDUC and CREDE) and of the schools themselves. The leaders who took over the schools starting in 2004 had a powerful planning and results management instrument within their reach: Integrated School Management (GIDE). ${ }^{8}$ Each school thus went on to assume a major responsibility in the promotion of the success of its students. It was not by chance that GIDE chose as pedagogical aims the "increase of passing and dropout reduction, improvement of the SPAECE indicators, and increase of approval on colleges and universities entrance exams and/or civil service exams" (Ceará, 2005b, p.18).

In addition to this management tool, the public schools of the state system have the System for Following Performance and School Routine (SADRE) software, ${ }^{9}$ which makes possible on-line interaction of all the schools with CREDE and SEDUC.

Dissemination of the results of SPAECE and incorporation of indicators of the school movement (passing and dropout rates above all) are important steps in building a culture of evaluation. It should be associated, however, with a group of other instruments about which we still know little. In the following we will examine some measures that have been adopted to help light up the roads for the short, medium and long terms.

Pioneer studies of SEDUC detected the presence of significant discrepancies between the master curricula adopted by the central organ and that which, in fact, is developed in the classroom.

Such deconstructing demonstrated the need to find ways to bring the theoretical and the real curricula closer together. This approximation requires a two-way street -from the system to the school and from the school back to the system - in a permanent dialogue, aiming to overcome the gap between what the evaluation system seeks to measure and the teaching given by the teachers. This alignment is indispensable for the improving the results of the evaluations provided by the systems.

Workshops for the construction of SPAECE items represent a step in this direction. By relying on teachers from the public (state and municipal) system with orientation by specialists, revision of the master plans can be accomplished and the elaboration of items passible to be selected for the SPAECE tests. Effectively working with the teachers who can be found in the classroom, we seek to approximate the matrices over which SPAECE positioned itself in daily school life and the actual curriculum, ${ }^{10}$ which takes place in the classroom. The intention of this is to strengthen the community of teachers so that they can take over the place of active subjects in the definition of a culture of evaluation. Alongside this work, an attempt was made to define other equally significant procedures for supporting and strengthening the school.

Among the initiatives that began to be developed in 2005, some deserve highlighting. One of them is the offer of 2,500 specialization scholarships for teachers from the state system in basic disciplines of the High School curriculum, 500 of which involved non-site teaching of Portuguese and mathematics. These courses seek to focus on specific questions concerning the teaching-learning 
process for this level of teaching and be a strategy for enhancing teacher valuation, making it possible for the teachers to acquire a post-graduate level degree lato sensu.

The Learning Agent Project (AgeAp) was another measure which aimed to improve student preparation for SAEB 2005. This work was continued in 2006, aiming toward the application of a new step of SPAECE. The first results of the work in progress created a belief that there is strong innovative potential in the idea of Learning Agents which with necessary adjustments could flourish in a positive manner in the schools.

From the perspective of selection of projects by public edict that were inaugurated in the period 2003-2005, considerable resources (c. $\$ 750,000$ ) came to be designated for presentation of proposals for the improvement of the teaching of Portuguese and mathematics and the reduction of school dropout.

An important component of management for a community of learners is the Spotlight School Prize, implemented in 2005. Conceived within the aegis of the Modernization and Improvement of Basic Education Program (PMMEB), with support from the previously mentioned Institute of Research and Economic Strategy of Ceará (IPECE), the prize seeks to stimulate the school units that continue improving relative to their performance, by observing improvement indicators - rates of passing and dropout - and the results reached in SPAECE measured student school performance. It is important to highlight that the prize was conceived in two categories, and $80 \%$ of them are directed to the performance improvement from year to year, and $20 \%$ to the absolute best results according to SPAECE.

All the measures referred to here were adopted with the explicit end of developing strategies to strengthen the school as a community of learners. The expectation was that in them they would find fertile soil, germinate and flourish. For rather more important than effort and the commitment to a management system is a disposition to teach and learn that depends to a considerable extent on the school itself, above all its teachers and students. The road to school success requires simple things like time of exposure to the material. Teaching and learning. Learning and teaching. No formula has been discovered that can dispense with effort, dedication and will. The specially talented, perhaps, do not need these simple and necessary ingredients. The great majority do. For this reason, impregnating the school ambience with the essence of learning is a task for all that cannot be postponed. In making this choice, the management will be contributing so that the school comes to constitute the community of learners that Ceará wants, needs and deserves.

\section{Some victories - the risks of discontinuity}

Lourenço Filho (1940, p.15), mentor of Ceará's 1922 educational reform, said on one occasion that "education is a job that never ends. It can never be perfect simply because the government leaders want it." This reformer of the past expressed a question that continues to the present. It is not because much has 
been done that the work has been completed. Clearly not. Much has been done. And there is so much more to do. Preoccupation with what enables the transition between present and future is what should be continued, as well as preoccupation with what should be modified in the measures adopted for promoting management for a community of learners. The risks of discontinuity, like a spectre surrounding public policies, make it necessary to continually reinvent the wheel.

Some aspects of the work developed in the period 2003-2006 the progress of which we are reporting here was directed toward organization of the system, with a goal of promoting a culture of school success. Some of the results in this direction express themselves in numbers, as an example of improvement of the indices of approval of public system students on entrance exams. Thanks to the support of one of the developed partnerships (Lemann Foundation), Ceará had the pleasure of seeing a student from one of its public schools admitted to ITA (Technological Air Institute), as well as admission to other competitive courses like Medicine, Dentistry and Law. More than merely making a point, this exception illustrates an explicit movement in the search for school success. The state schools of Ceará have not only developed initiatives of reinforcement for the students of the $3^{\text {rd }}$ year of the High School, but are also proudly monitoring results of the entrance exam to colleges and universities. From going in the wrong direction of prejudice and depreciation of the public school, the idea of school success has begun to find soil in which to grow.

If education is work "that never ends," it must be expected that responses to the initiatives will be slow. The results obtained are still only slightly visible, but some indicators allow an inference that Ceará is searching on the right road, although the performance of its students on the evaluation systems considered here does not yet arouse enthusiasm.

The SAEB data is well known and, in a general manner, expresses a common tendency of the break in the country from 1995/1997 and ahead, that only begins to be reversed from 2003 on. Within this scenario, Ceará reached second place in proficiency in the Northeast High School (Portuguese and Mathematics) in 2005. In the Fundamental School, however, there is no special state performance highlight, for which the same may be said with regard to the Brazil Test (Prova Brasil).

Data from ENEM-2006 shows that while students from Ceará have had superior results within the overall region, these indices are still on a level beneath the data of the country in general. As we can see:

\begin{tabular}{l|c|c|c|c|c}
\hline \multirow{2}{*}{ Region/UF } & \multicolumn{3}{|c|}{ Total } & \multicolumn{2}{c}{ Type of High School attended } \\
\cline { 2 - 6 } & General & Graduated & Dropout & $\begin{array}{c}\text { Public school } \\
\text { only }\end{array}$ & $\begin{array}{c}\text { Private school } \\
\text { only }\end{array}$ \\
\hline Brasil & 36.90 & 35.52 & 38.14 & 34.94 & 50.57 \\
\hline Northeast & 33.83 & 32.68 & 34.93 & 32.39 & 46.44 \\
\hline Ceará & 34.74 & 33.39 & 36.52 & 33.08 & 45.57 \\
\hline
\end{tabular}


As to the elaboration of the school management tool (GIDE) previously mentioned, three school indicators were selected to establish multi-year, annual, global and stratified goals: rate of passing, dropout rate and school performance from SAEB and SPAECE

The work developed in the years that GIDE has been in use still does not make it possible to analyze the impact more accurately in using these indicators for medium-range undertakings.

However INEP, by establishing the Index of Development of Basic Education(IDEB), selected two of the indicators present in GIDE - rate of passing and school performance -, which confirms the relevance of the instrument developed in Ceará.

The 2005 indicators show the State of Ceará in first place among the Northeast states in the IDEB High School. In fact, due to the lack of an historical record, it is not desirable to directly associate such results to the work done with GIDE, although studies show the serious difficulties faced by the High School, especially in which they refer to dropout rate and student performance.

IDEB (2005), passing rate and performance on SAEB (2005) of the High School State System from the Northeast.

\begin{tabular}{|c|c|c|c|c|c|c|c|c|c|c|c|c|c|c|}
\hline \multirow[b]{2}{*}{ Abbr. } & \multirow[b]{2}{*}{ State } & \multicolumn{4}{|c|}{$\begin{array}{l}2005 \text { Passing Rate } \\
\text { High School }\end{array}$} & \multirow{2}{*}{$\begin{array}{c}\text { Add } \\
\text { of } \\
1 / p\end{array}$} & \multirow[b]{2}{*}{$\mathbf{T}$} & \multicolumn{4}{|c|}{$\begin{array}{l}\text { Saeb } 2005-3^{\text {rd }} \text { grade } \\
\text { State High School }\end{array}$} & \multirow[b]{2}{*}{$\begin{array}{l}P= \\
1 / T\end{array}$} & \multirow[b]{2}{*}{$\mathbf{N}$} & \multirow{2}{*}{$\begin{array}{l}\text { Ideb } \\
=\mathrm{N} \\
\mathrm{XP}\end{array}$} \\
\hline & & $1^{\text {st }}$ & $2^{\text {nd }}$ & $3^{\text {rd }}$ & $4^{\text {th }}$ & & & Math & $\begin{array}{l}\text { Portu- } \\
\text { guese }\end{array}$ & $\begin{array}{c}\text { Standard } \\
\text { Grade } \\
\text { Mathe- } \\
\text { matics }\end{array}$ & $\begin{array}{c}\text { Standard } \\
\text { Grade } \\
\text { Portu- } \\
\text { guese }\end{array}$ & & & \\
\hline $\mathrm{AL}$ & Alagoas & 60.9 & 70.5 & 79.2 & 94.9 & 5.4 & 1.3 & 251.5 & 235.8 & 3.9 & 3.6 & 0.74 & 3.8 & 2.8 \\
\hline BA & Bahia & 57.0 & 69.4 & 77.1 & 89.8 & 5.6 & 1.4 & 255.3 & 237.1 & 4.1 & 3.6 & 0.71 & 3.8 & 2.7 \\
\hline CE & Ceará & 62.3 & 73.1 & 79.7 & 86.9 & 5.4 & 1.3 & 253.8 & 248.3 & 4.0 & 3.9 & 0.74 & 4.0 & 3.0 \\
\hline MA & Maranhão & 63.9 & 72.2 & 82.4 & 86.5 & 5.3 & 1.3 & 229.9 & 222.6 & 3.3 & 3.2 & 0.75 & 3.3 & 2.4 \\
\hline PB & Paraíba & 61.7 & 70.3 & 80.5 & 92.6 & 5.4 & 1.3 & 242.4 & 229.7 & 3.7 & 3.4 & 0.75 & 3.5 & 2.6 \\
\hline PE & Pernambuco & 61.7 & 71.1 & 74.2 & 89.9 & 5.5 & 1.4 & 243.0 & 240.2 & 3.7 & 3.7 & 0.73 & 3.7 & 2.7 \\
\hline $\mathrm{PI}$ & Piauí & 57.7 & 70.3 & 79.3 & 57.6 & 6.2 & 1.5 & 239.8 & 234.3 & 3.6 & 3.5 & 0.65 & 3.6 & 2.3 \\
\hline $\mathrm{RN}$ & $\begin{array}{l}\text { RN R. G. } \\
\text { Norte }\end{array}$ & 61.0 & 70.3 & 78.7 & 83.8 & 5.5 & 1.4 & 244.9 & 232.7 & 3.8 & 3.5 & 0.72 & 3.6 & 2.6 \\
\hline SE & Sergipe & 57.0 & 69.9 & 76.7 & 91.7 & 5.6 & 1.4 & 254.7 & 247.0 & 4.0 & 3.9 & 0.72 & 4.0 & 2.8 \\
\hline
\end{tabular}

Caption - T: average time for finishing a grade (years), $\mathrm{N}$ : average standard grade.

Source: Inep/MEC 2007.

As can be seen in the table above, the passing rate in the High School of the state system of Ceará shows results that are above average when compared to other states of the Northeast Region. The same can be seen in relation to the results of SAEB 2005, applied in the $3^{\text {rd }}$ grade of the High School.

More than mere symptoms, these small advances are signs that the situation is beginning to change. Certainly it is still little. Very little in face of the immense challenge of advancing the quality of Basic Education. The effects of planning policies, management and evaluation for school success are long term.

The risks of discontinuity, however, can have immediate effects. In such circumstances it is opportune to remember that as important as it is to analyze 
what has been done, it is pertinent to also discuss what can and must be done to assure the continuity of successful initiatives. It would be shackling the advance of Brazilian education to subordinate its policies to the whim of governments that come and go (Cunha, 2005; Garcia, 1991). Denunciation of incessant rebeginnings has been expressed for a long time by specialists in the area, but the wheel keeps being reinvented and discontinuity continues. Meanwhile we still owe the children, the young people and Brazilian adults the education that they need and deserve to have.

\section{Notes}

1 Translators note: "Basic Education encompasses three levels: "Infantil," "Fundamental" and "Médio" Schools, or here as Infancy, Fundamental and Middle. Infancy School ranges from age 3 months to 6 years, more or less like U.S. pre-school and kindergarten; Fundamental School is a 9 year/grade school; and Middle School is a 3 year/grade school beginning at about age 15 . The names Infant and Fundamental are without the confusion introduced by a translation of "Médio" - in virtually all instances rendered into English as a version of "middle"-including its use in sports as midway, midfield or intermediate - particularly since American education has introduced a "Middle" school itself that except for the possible inclusion of one or two lower grades is essentially the same as Junior High School, i.e., between Primary (or Grade, Grammar or Elementary school as it is also known) and Senior High School (also considered Secondary School, or most often as just "High School."

2 Such information can be found in the Mensagens, referring to the period of the last two terms of Tasso Jereissati, which encompasses the period from 1995 to 2002. For an appreciation about education in the so-called "governo das mudanças", see Ramos (2005).

3 This reflection will be more fully explored later when we consider the Evaluation System of Basic Education (SAEB) and the Permanent Basic Evaluation System of Ceará (SPAECE).

4 See, in connection, the National Education Plan (PNE) (2000), sanctioned by Law $\mathrm{n}^{\circ}$ $10.172 / 2001$, which considers an excessively full agenda of objectives and goals, with which the difficulty of complying has been evident in the period observed.

5 The principles defined were: education of quality and social inclusion; democratic management and social control; action sharing public power and society and permanent professional development and valuing the workers in education. The programs, by their turn, were the following: progressive extension of the High School in urban and rural locations; support for the development of Infant Education and the implementation of policies of inclusion for youth and adults, special educational needs and indigenous communities; reduction of youth and adult illiteracy; guarantee of school quality with a focus on student learning; guarantee of dominion over reading, interpretation and writing abilities; progressive amplification of the school period; improvement of the process of preparing and giving value to workers in education; modernization of the process of management and social control of the school system; perfecting the institutional evaluation process and of the educational results analysis; regulating and putting into effect a regime of Municipal/State collaboration. For more clarifications related to the Plan, refer to Ceará (2004a).

6 In this regard a recorded example from Almeida $(1989$, p.89) is illustrative, who in a book originally published at the end of the Monarchy expressed with respect to the public school: "There is a preconception against the public school that will be very difficult to completely root out; nothing is learned, as it is generally said. There are, in fact boys and girls twelve years old or 
more that attended public schools and are incapable of writing anything by themselves: they know only how to count or only know how to read."

7 Starting in 2005, SAEB went on to become a system composed of two evaluations: National Evaluation of Basic Education (ANEB) and the National Educational Outcome Evaluation (ANRESC), also known as Brazil Test ("Prova Brasil"). The first mode maintains biennial sample evaluations about student proficiency in the public and private Brazilian school systems. The second, in turn, gathers information about the performance of each one of the urban schools, with more than 30 students from the $4^{\text {th }}$ to $8^{\text {th }}$ grades of the Fundamental School in the Brazilian public system, offering an evaluation of schools from the public system with an aim toward improving planning and the application of resources for the improvement of the quality of the system.

8 The Integrated School Management (GIDE) was a byproduct of the strategic formulation process of SEDUC with the objective of improving communication between SEDUC/CREDE/School by focussing on the school. It also aims at the avoidance of superimposing management tools and duplication of the work of the School Community, promoting an economy of people's time, talent and energy by the adoption of a single management tool focussed on results. The work was developed starting from a meticulous analysis of the Pedagogical Policy Project (PPP), Development of School Plan (PDE) and from the tools available in the Program of Modernization and Improvement of Basic Education (PMMeB) which were present simultaneously in Ceará's schools, provoking significant managerial dissatisfaction from the fact of their having to prepare three separate documents. The intent, beginning with integrated planning of the strategic, pedagogical and managerial dimensions, was to maximize and bring results into alignment. For more information, consult Ceará (2006).

9 SADRE is software that allows real time information (internet) for the three instances of the educational system, independently of geographical location to be feasible; it condenses and refines results through reports and goal monitoring to make information available on a democratic basis, and functions as a follow-up and assessment assistance tool based on facts and data.

10 It is important to point out that many times the actual curriculum is greatly inferior in quantity and quality to that envisioned by the Common National Base. This diagnostic which is conducted in partnership with the teachers enables the teachers, in addition, to review what they have been working with and advance in their effort to get closer to the basic standard which is recognized as the minimum necessary for that grade or level of teaching.

\section{Bibliography}

ALMEIDA, J. R. P. História da Instrução Pública no Brasil (1500 - 1889). Brasília:Inep/PUC-SP. 1989. BRASLAVSKY, C. Dez fatores para uma educação de qualidade para todos no século XXI. São Paulo: Moderna, 2005.

CEARÁ. Seduc. Plano de Educação Básica - escola melhor, vida melhor (2003-2006). Fortaleza, 2004a. Seplan/Ipece. Holanda, Marcos Costa, Rosa, Antonio Lisboa Teles da. Gestão por resultados na perspectiva do Estado do Ceará. Nota Técnica 11. Fortaleza, out. 2004b. Spaece - 2004. Relatório Geral. Fortaleza: Edições Seduc, 2005a.

Revista Spaece. Fortaleza: Edições Seduc, 2005b.

Gestão integrada da escola. Fortaleza: Edições Seduc, 2006.

SIM. Relatório de desempenho das metas de inclusão social-2004. Fortaleza, s. d.

CORDEIRO, C. Exposição oral sobre o Relatório de Desempenho das Metas de Inclusão Social - 2004. Seminário "Gestão pública a serviço da inclusão". 2004. 
CUNHA, L. A. Educação, estado e democracia no Brasil. São Paulo: Cortez, 1991.

Gestão para uma comunidade de aprendizes. In: SEDUC. Gestão escolar e qualidade da

educação. Fortaleza: Edições Seduc, 2005. p.9-23.

GARCIA, W. E. Administração educacional em crise. São Paulo: Cortez Autores Associados, 1991.

LOURENÇO FILHO, M. B. Entrevista - A vida e obra de nossos educadores. Formação - Revista de Educação, Rio de Janeiro, n. 19, Ano III, p.15, fev. 1940.

LUCE, M. B.; MEDEIROS, I. L. P. Gestão escolar democrática: concepções e vivências. Porto Alegre:

Editora da UFRGS, 2006. p.27-42.

OCDE. Aprendendo para o mundo de amanhã: primeiros resultados do Pisa 2003. Organização para Cooperação e Desenvolvimento Econômicos (OCDE). São Paulo: Moderna, 2005.

PENIN, S.; VIEIRA, S. L. Refletindo sobre a função social da escola. In. VIEIRA, S. L. (Org.) Gestão da escola: desafios a enfrentar. Rio de Janeiro: DP\&A, 2002. p.13-45.

RAMOS, J. F. P. Gestão democrática da escola pública: a experiência do governo das mudanças (19952001). Fortaleza: UECE, 2005.

SEDUC. Gestão Integrada da Escola 2007. Secretaria da Educação Básica do Estado do Ceará.

Fortaleza. Edições Seduc, 2006.

UNESCO. Relatório de Monitoramento Global de EPT 2005: educação para todos: o imperativo de qualidade. São Paulo: Moderna, 2005.

VIEIRA, S. L. Educação e gestão: extraindo significados da base legal. In: LUCE, M. B.; MEDEIROS, I. L. P. Gestão escolar democrática: concepções e vivências. Porto Alegre: Editora da UFRGS, 2006, p.27-42.

VIEIRA, S. L.; VIDAL, E. M. A educação brasileira ficando "mais" para trás. In: XVIII Encontro de Pesquisa Educacional do Norte e Nordeste. Maceió, Alagoas, 2007a.

VIEIRA, S. L.; VIDAL, E. M. Educação básica: a equidade numa perspectiva territorial. In: XVIII Encontro de Pesquisa Educacional do Norte e Nordeste. Maceió, Alagoas, 2007b.

ABSTRACT - The article analyses education policies adopted by schools in the state of Ceará, Brazil, from 1995 to 2006, concentrating on the period of 2003-2006. The key issues are educational management, evaluation and school success. The study presents ideas about the assessment systems at the state and national levels; "management for results," the use of indicators for defining priorities; and diffusion of an evaluation culture within the educational system.

KErWORDS - Educational Policy, Educational Management, Educational Evaluation.

Sofia Lerche Vieira is a PhD in Philosophy and History (PUC/SP); Professor at UECE; Researcher at CNPq. Secretary of Basic Education of the State of Ceará (2003-2005). @ - sofialerche@yahoo.com.br.

This text has been translated by Cary Wasserman and Valéria Wasserman. The original in Portuguese - "Gestão, avaliação e sucesso escolar: recortes da trajetória cearense" - is available at http://www.scielo.br/scielo.php/script_sci_serial/lng_pt/pid_0103-4014/ nrm_iso.

Received on 6.5.2007 and accepted on 6.12.2007. 